\title{
Work Motivation:
}

\section{Correlation of Teacher Performance in State Vocational High Schools}

\author{
Devi Pramiati Agustriani* \\ Educational Administration Department \\ Universitas Pendidikan Indonesia \\ Bandung, Indonesia \\ *devi.pramiati@upi.edu
}

\author{
Nur Aedi \\ Administration of Education \\ Universitas Pendidikan Indonesia \\ Bandung, Indonesia
}

\begin{abstract}
This study aims to determine the effectiveness of work motivations on teacher performance at SMK Negeri 1 Cisarua, West Bandung District. To prove the hypothesis in this study, the data collection methods used were questionnaire and documentation techniques. The validity test used Pearson's product moment correlation technique. While the reliability test used Alpha Cronbach technique with the help of SPSS 16. Furthermore, to determine the results of the data collected, calculations were carried out using simple linear regression techniques. The results of this study indicate that there is a significant influence between work motivations on teacher performance at SMK NEGERI 1 CISARUA, West Bandung District with the correlation of the independent variables with the significant level. This means that the contribution of variable $X$ (work motivation) to variable $\mathrm{Y}$ (teacher performance) is $\mathbf{2 3 . 7 \%}$. So that the remaining $\mathbf{7 6 . 3 \%}$ of other factors can affect the motivation of teacher performance at SMK Negeri 1 Cisarua West Bandung District.
\end{abstract}

Keywords-correlation, teacher performance, work motivation

\section{INTRODUCTION}

The definition of education according to the Law of the Republic of Indonesia Number 20 of 2003 concerning the National Education System is a conscious and planned effort to create an atmosphere of learning and the learning process so that students actively develop their potential to have religious spiritual strength, self-control, personality, intelligence, noble character, and skills needed by themselves, the community, nation and state [1].

Improving the quality of education is a development goal in the national education sector and is an integral part of efforts to improve the overall quality of Indonesian people. The government, in this case the Minister of National Education has launched the "Movement for Improving the Quality of Education" on May 2, 2002, and is more focused, after being mandated in Law of the Republic of Indonesia No. 20 of 2003 concerning the National Education System, that national education functions to develop capabilities and to form a dignified national character and civilization in the context of the intellectual life of the nation, aiming at developing the potential of students to become human beings who believe and fear God Almighty, have noble character, are healthy, knowledgeable, capable, creative, independent, and become citizens democratic and responsible [1].

Mulyasa's opinion "Employees (teachers) will work sincerely if they have high motivation, if he has positive motivation, he will show interest, have attention, and want to participate in a task or activity" [2]. In accordance with this opinion, teachers who are still less successful in teaching are because they are less motivated to teach so that it has an impact on decreasing teacher productivity or performance. For this reason, the role of the principal is needed to motivate teachers to improve their performance.

The quality of education at the education unit level can be demonstrated by the phenomenon of schools that have advantages and are competitive. One indication of an advantageous and competitive school is the appearance of students' attitudes and behavior in accordance with applicable norms and an increase in student learning achievement, one of which can be seen from the percentage of graduation above the national standard.

The teacher is a component that occupies a central position and is very strategic in the education system. Teachers are the dominant factor in relation to improving the quality of education, because teachers are an inseparable part of the education system as a whole who is directly involved in the teaching and learning process, it is the teacher who has a direct role in teaching and educating. In this connection, it is necessary to carry out various programs to improve the quality of teacher performance in developing aspects of education and learning.

Many factors influence performance, including environment, management behavior, job design, performance appraisal, feedback and wage administration [3]. A person's performance is strongly influenced by the factors of ability, motivation, and opportunity, namely performance, which means that performance is a function of ability, motivation and opportunity [4]. Teacher performance can be shown from the teacher's ability to master the required competencies, namely pedagogical competence, personality competence, social competence, and professional competence [5]. 
As teaching professionals, teachers have different work motivation from one teacher to another. This will lead to differences in teacher performance in improving the quality of education. Herzberg states that "Work motivation is not a single dimension, but is composed of two factors, namely: motivational factors (satisfier) and hygiene factors" [6]. Motivating factors are factors that cause job satisfaction, such as job performance, recognition, progress, a feeling that what they do is important and responsibility. Hygiene factors are extrinsic factors, such as administrative policies, supervision, relationships with coworkers, salaries, security in work, personal life, working conditions and status. Teacher work motivation is an important factor in improving teacher performance because it is the main driving force for every teacher to carry out their professional duties according to applicable regulations.

Based on observations made in the field, so far the class visits conducted by the principal have not been optimal so that the principal has not been able to see the performance of teachers and problems faced in the classroom in more depth. In addition, in almost every school some teachers do not prepare complete teaching tools such as daily implementation plans, attendance, question grids, improvement programs, morals reports, KKM analysis. Thus, it can be concluded that low teacher work motivation will have an impact on low teacher performance results which can have implications for low student learning outcomes. Therefore, I am interested in conducting a study by looking at the level of teacher performance with the title "The Effect of Work Motivation on Teacher Performance at SMK Negeri 1 Cisarua, West Bandung District".

\section{STUDY OF THEORY AND HYPOTHESIS DEVELOPMENT}

\section{A. Performance}

The performance of an organization is strongly influenced by employee performance, while improving employee performance is closely related to the motivation of the employees themselves. Performance is the behavior of a person who produces certain work results after fulfilling a number of requirements [7]. Many factors affect performance, including the environment management behavior, job design, performance appraisal, feedback and wage administration [3].

Employee performance policy according to Prawirosentono states that "Performance is what is achieved by a person or group of people in the organization according to their respective responsibilities in order to achieve the goals of the organization concerned generously does not violate the law and is in accordance with morals and ethics" [8].

\section{B. Teacher Performance}

According to Clewes states that "The lecturer or teacher performance is an important factor. The students are the prime evaluator of the teacher performance (lecturer or teacher performance is an important factor, students are the main evaluator of teacher performance)" [9]. Teacher performance is the ability and success of teachers in carrying out learning tasks [3].

Teacher performance is the result of teacher work that is reflected in how to plan, implement and assess the teaching and learning process whose intensity is based on work ethic, as well as professional discipline in the learning process [7]

According to Mangkunegara states that performance with respect to the teaching profession is a real behavior shown by teachers when giving lessons to their students [10]. Teacher performance can be shown from the teacher's ability to master the required competencies, namely pedagogical competence, personality competence, social competence, and professional competence [5].

\section{Teacher Performance in Teaching and Learning Process}

The role of the teacher is influenced by their mastery of knowledge, how to provide subject matter, frequency of teaching and so on. According to Hadiyanto and Subiyanto [11], it is explained that a conducive learning climate can support: (1) beneficial interactions among students, (2) clarifying the experiences of teachers and students, (3) fostering an enabling spirit activity in class go well, and (4) support mutual understanding between teachers and students.

According to Nguni et al., stated that "teachers who are satisfied with their job are more enthusiastic and interested in devoting more energy and time to student achievement" [teachers who are satisfied with their work are more enthusiastic and interested in devoting more energy and time to student academic achievement] [12].

\section{Motivation}

Motivation comes from the word motive which can be interpreted as the power contained in an individual, which causes the individual to act or act. Motivation cannot be observed directly, but can be interpreted in behavior, in the form of stimulation, encouragement, or a power generator for the emergence of a behavior [13].

Motivation is the provision of the driving force that creates the excitement of a person's work, so that they are willing to cooperate, work effectively and be integrated with all his efforts to achieve satisfaction [14].

Teacher work motivation is measured in two dimensions, namely external motivation and internal motivation [15]. External motivations include: interpersonal relationships, payroll or honorarium, supervision of the principal, and working conditions. Internal motivation includes: drive to work, advancement in career, recognition gained, a sense of responsibility at work, interest in assignments, and drive to achieve.

According to Moekijat states that motivation is a driving force or incentive to do something [16]. 


\section{E. Work Motivation}

The view of work and work today is not like the conservative view which states that physical work is a form of punishment so that people don't like it. However, nowadays, work and work have become necessities.

According to Mangkunegara motivation is an impulse that arises in a person who moves him to do something [17]. Teachers who have high work motivation will always work hard to overcome all kinds of problems faced in the hope of achieving better results.

According to Steyn "argues that effective principals are able to create an ethos that generates motivated and successful teachers and stimulated and inspired learners in an effective school setting" [18] and successful and stimulated learners to be inspired in effective school settings.

\section{F. The Nature of Teacher Work Motivation}

Work motivation is not only in the form of economic interests, but usually also in the form of a psychological need to do more active work. According to Dimyati "motivation is a mental impulse that drives and directs human behavior" [19]. Motivation is often said to be the key to work creativity. Work creativity can be enhanced by high work motivation, knowledge and expertise in performing tasks and the positive role a person has.

\section{HYPOTHESIS}

The development of the hypotheses developed in this study are as follows:

- $\mathbf{H}_{\mathbf{0}}$ : There is no positive and significant influence between work motivation on teacher performance at SMKN 1 Cisarua, West Bandung District.

- $\mathbf{H}_{\mathrm{a}}$ : There is a positive and significant influence between work motivation on teacher performance at SMKN 1 Cisarua, West Bandung District.

\section{RESEARCH METHODS}

\section{A. Research Population}

As for the author's population in this study were 65 people from the teaching staff and educational staff at SMKN 1 Cisarua, West Bandung District.

\section{B. Research Samples}

The sample is a part that is taken from the whole object under study or a set of elements to be studied and is considered to represent the entire population which is taken by saying a certain technique. Suharsimi Arikunto in another book that is for illustration or a guide, so if the subject is less than 100, it's better to take all of them, so that the research is a population study [20]. We recommend that if the subject is large above 100 , the percentage can be taken in the range of $10-15 \%$ or 20 $25 \%$.
With the guidelines above, the number of teachers who became the population in this study the authors made the total sample, so that in the study the author would use this type of population research, because the entire population in the research place totaling 65 people was used as the total sample, the sample in this study was also taken from the staff. teachers of SMK NEGERI 1 CISARUA, to be a test indicator in this study.

\section{Operational Definition and Variable Measurement}

1) Teacher work motivation: According to Mangkunegara defines motivation as an impulse that arises in someone who moves to do something [17]. Teachers who have high work motivation will always work hard to overcome all kinds of problems faced in the hope of achieving better results. Indicators of teacher work motivation are: [a] Need for achievement, [b] Opportunities for development, [c] Pride in one's own work, [d] Need for recognition, and [e] Salary received.

2) Teacher performance: According to Rusman [21], with regard to the importance of teacher performance appraisal, the Georgia Department of Education has developed a teacher performance assessment which was later modified by the Ministry of National Education to become a Teacher Performance Assessment Tool [APKG developed by the Primary and Secondary Education Development project. These indicators are: (1) teaching plans, (2) teaching implementation, (3) interpersonal relationships, and (4) evaluation.

\section{Analysis Technique}

This study uses a questionnaire method in data collection. The instrument used in data collection was a questionnaire on work motivation and teacher performance. The data analysis technique used in this research is simple correlation analysis. This analysis is used to find out the relationship between the independent variables and the dependent variable. The correlation technique used is Pearson Product Moment.

\section{E. Hypothesis Testing}

In this study, to test the hypothesis using the $\mathrm{t}$ test. The $\mathrm{t}$ test is a partial test used to test the relationship between the independent variables individually and the dependent variable [22].

\section{RESULTS AND DISCUSSION}

\section{A. Simple Linear Regression Analysis}

Reliability test is used to determine the consistency of measuring instruments and to show the extent to which these measuring instruments can be trusted and relied on in research. In this case, the reliability test was carried out using Cronbach Alpha with the help of the SPSS program, with the criteria that the results of the alpha count $>0.60$, so the data tested had a 
good level of reliability. The results of the SPSS output can be seen in table 1 and table 2.

TABLE I. RELIABILITY TEST RESULTS (X)

\begin{tabular}{|c|c|c|c|}
\hline No & Variable & Alpha Cronbach & Information \\
\hline 1 & Effect of Work Motivation & 0.956 & Realiable \\
\hline
\end{tabular}

Source: primary data processed in 2020

From the results of the reliability test, it can be seen in the output reliability statistic that the Cronbach's Alpha coefficient calculation above is $0.956>0.60$, so it can be concluded that the measuring instrument in the study is realistic.

TABLE II. RESULTS OF THE Y VARIABLE RELINABILITY TEST

\begin{tabular}{|c|c|c|c|}
\hline No & Variable & Alpha Cronbach & Information \\
\hline 1 & Teacher Performance & 0.944 & Realiable \\
\hline
\end{tabular}

Source: primary data processed in 2020

From the results of the reliability test, it can be seen from the output reliability statistic that the Cronbach's Alpha coefficient calculation above is $0.944>0.60$, so it can be concluded that the measuring instrument in the study is realistic. From the results of the reliability test above, it is found that the Alpha value of work motivation [X] is 0.944 and teacher performance [Y] is 0.944 and the conclusion is that the questionnaire used in this study is declared reliable because the value is $>0.60$. This means that the measuring instrument used in this study already has the ability to provide consistent results in measuring the same symptoms.

\section{B. Hypothesis Testing}

Hypothesis is a provisional assumption on the formulation of the problem, for that the hypothesis must be tested empirically. Hypothesis testing in this study uses Product Moment correlation analysis. The analysis is used to determine the correlation coefficient either individually or collectively. The hypotheses tested are as follows:

- $\mathbf{H}_{\mathbf{0}}$ : "There is no positive and significant influence between Work Motivation on Teacher Performance in SMK Negeri 1 Cisarua, West Bandung District"

- $\mathbf{H}_{\mathbf{a}}$ : "There is a positive and significant influence between Work Motivation on Teacher Performance in SMK Negeri 1 Cisarua, West Bandung District." Correlation coefficients are sought to test the hypothesis and see how much influence Work Motivation [X] has on Teacher Performance [Y].

Based on the analysis that has been carried out using the help of the SPSS version 16.0 for Windows computer program, the correlation coefficient between $\mathrm{X}$ and $\mathrm{Y}$ is 0.648 . The correlation coefficient value is then consulted with the correlation coefficient table as follows (table 3 ).
TABLE III. HYPOTHESIS CORRELATION TEST

\begin{tabular}{|c|c|c|c|}
\hline \multicolumn{2}{|c|}{} & Motivation & $\begin{array}{c}\text { Teacher } \\
\text { Performance }\end{array}$ \\
\hline \multirow{4}{*}{ Motivation } & Pearson Correlation & 1 & $.648^{* *}$ \\
\cline { 2 - 4 } & Sig. (2-tailed) & & .000 \\
\cline { 2 - 4 } & $\mathrm{N}$ & 37 & 37 \\
\hline $\begin{array}{c}\text { Teacher } \\
\text { Performance }\end{array}$ & Pearson Correlation & $.648^{* *}$ & 1 \\
\cline { 2 - 4 } & Sig. (2-tailed) & .000 & \\
\cline { 2 - 4 } & N & 37 & 37 \\
\hline
\end{tabular}

\section{Coefficient of Determination}

TABLE IV. CORRELATION COEFFICIENT OF X TO Y

\begin{tabular}{|c|c|c|c|}
\hline Correlation & R count & R table & $\mathbf{R}^{\mathbf{2}}$ \\
\hline $\mathrm{X}$ against $\mathrm{Y}$ & 0,648 & 0,325 & 0,237 \\
\hline
\end{tabular}

The table 4 shows that $\mathrm{r}$ count is greater than $\mathrm{r}$ table [0.648> 0.325], so it can be concluded that Ho says "rejected". On the other hand, Ha is "accepted".

Based on the table above, it is also obtained the correlation value between $\mathrm{X}$ and $\mathrm{Y}$ of $64.8 \%$. explained by Variable $\mathrm{X}$ and about $[100 \%-23.7 \%=76.3 \%]$ explained by other causes. In other words, work motivation has an effect on teacher performance by $23.7 \%$. And $76.3 \%$ is another factor that can affect teacher performance.

\section{CONCLUSIONS AND RECOMMENDATIONS}

\section{A. Conclusion}

Work motivation has a significant influence on teacher performance at SMK Negeri 1 Cisarua, West Bandung District according to the results of the determination analysis $\mathrm{R} 2[\mathrm{R}$ Square]. This shows that between work motivation.

$[\mathrm{X}]$ with the performance of teachers at SMK Negeri 1 Cisarua, West Bandung District [Y] there is a positive effect, and the rest is influenced by other variables.

In the multi-variable correlation analysis test, it can be seen that the independent variable $\mathrm{X}$ [work motivation] shows that work motivation has a positive influence on the performance of teachers in SMK Negeri 1 Cisarua, West Bandung District. This study also provides a clear description that high work motivation will affect the performance of teachers in SMK Negeri 1 Cisarua, West Bandung District.

\section{B. Suggestion}

Based on the results of the research, several things can be suggested, especially to teachers and the SMK Negeri 1 Cisarua, West Bandung District as follows: 
- The Effect of Work Motivation on Teacher Performance at SMK Negeri 1 Cisarua, West Bandung Regency is very good. Thus, this situation should be further enhanced by efforts to implement good governance, namely through participation, transparency and accountability.

- Teacher work motivation has shown a very good tendency, this should be improved, even more so that students have good achievements in both academic and non-academic fields and can produce graduates who are ready to work.

- Other researchers are expected to be able to develop research by conducting research on other variables such as principal leadership, teacher professionalism, teacher performance and the work environment that can affect teacher work motivation, as well as conducting on a wider population and using other research designs.

- Schools should provide adequate facilities in learning so that they can support the improvement of teacher performance at SMK Negeri 1 Cisarua, West Bandung District.

\section{ACKNOWLEDGMENT}

The author would like to say thank you very much to the academic supervisor Dr. Nuraedi, M.Pd. and the 4th ICREAM committee team who have facilitated the author in publishing this paper.

\section{REFERENCES}

[1] Undang- Undang RI No. 20 Tahun 2003 Tentang Sistem Pendidikan Nasional. Bandung: Penerbit Citra Umbara.

[2] E. Mulyasa, Manajemen Berbasis Sekolah: Konsep, Strategi dan Implementasi. Bandung: PT.Remaja Rosdakarya, 2004.

[3] S. Supardi, Kinerja Guru. Jakarta: Rajawali Press, 2012.
[4] S.P. Robbins and T.A. Judge, Perilaku Organisasi(Organizational Behavior). Jakarta: Salemba Empat, 2012.

[5] Undang- Undang Republik Indonesia tentang Guru dan Dosen. Jakarta, Nomor 14 Tahun 2005.

[6] F. Herzberg, Motivation to work. Routledge, 2017.

[7] H.B. Uno and N. Lamatenggo, Teknologi informasi dan komunikasi. Jakarta: Bumi Aksara, 2014.

[8] S. Prawirosentono, Kebijakan Kinerja Karyawan. Yogyakarta: BPFE, 1999.

[9] D. Clewes, "A student-centred conceptual model of service quality in higher education,” Qual. High. Educ., vol. 9, no. 1, pp. 69-85, 2003.

[10] A.P. Mangkunegara, Evaluasi Kinerja MSDM. Bandung: PT. Refika Aditama, 2007.

[11] H. Hadiyanto and S. Subijanto, "Pengembalian Kebebasan Guru untuk Mengkreasi Kelas dalam Manajemen Berbasis Sekolah (MBS),” J. Pendidik. Dan Kebud., no. 40, pp. 1-18, 2003.

[12] S. Nguni, P. Sleegers, and E. Denessen, "Transformational and transactional leadership effects on teachers' job satisfaction, organizational commitment, and organizational citizenship behavior in primary schools: The Tanzanian case," Sch. Eff. Sch. Improv., vol. 17, no. 2, pp. 145-177, 2006.

[13] H.B. Uno, The Theory of Motivation and Measurement. Jakarta: BumiAksara, 2007.

[14] M.S.P. Hasibuan, Manajemen: Dasar, Pengertian Dan Masalah (Edisi revisi). Jakarta: Bumi Aksara, 2007

[15] R. Riduwan. Metode Dan Teknik Menyusun Proposal Penelitian. Bandung: Alfabeta, 2010.

[16] Moekijat, Dasar-dasar Motivasi. Jakarta: Penerbit Pionir Jaya, 2002.

[17] A.P. Mangkunegara, Manajemen Sumber Daya Manusia Perusahaan. Bandung: PT. Remaja Rosdakarya Aditama, 2011.

[18] G.M. Steyn, "The changing principalship in South African schools," Educare, vol. 31, no. 1_2, pp. 251-274, 2002.

[19] M. Dimyati, Belajar dan pembelajaran. Jakarta: Rineka Cipta, 2006

[20] S. Arikunto, Prosedur penelitian pendidikan. Jakarta: PT Rineka Cipta, 2010.

[21] R. Rusman. Pendekatan dan Model Pembelajaran. Bandung: Universitas Pendidikan Indonesia, 2006

[22] S. Santoso, Buku Latihan Statistik Parametrik. Sidoarjo: Penerbit CV. Citramedia, 2001 